\title{
VEGETATION BASELTNE STUDY FOR THE \\ KNIFE RIVER INDIAN VILLAGES NATIONAL HISTORIC SITE
}

\author{
Gary K. Clambey \\ Department of Botany/Biology \\ North Dakota State University \\ Fargo
}

\section{Objectives}

Objectives of this study include:

1. An inventory of the flora, together with establishment of reference plant collection;

2. Delimitation and description of the piant communities, including compositional analysis;

3. Assessment of the contemporary plant cover relative to various management considerations, such as:

a. The use of prescribed burning, particularly in grassland areas;

b. Control of nuisance plant species, e.g., leafy spurge, poison ivy;

c. Present vegetative cover on formerly disturbed land and further efforts to restore or increase native species on those sites;

4. Clarification of vegetation patterns as they might have existed in the 1804-05 period.

\section{Methods}

Multiple ground surveys during the summer were used to meet all or parts of the first three objectives. Plant specimens were collected at these times and preserved for a permanent collection.

Plant communities were sampled by the quadrat method. This included $400-\mathrm{m}^{2}$ circular plots for woodlands and a total of 83 such areas were sampled. Nested $1-\mathrm{m}^{2}$ quadrats were used for the woodland understory, with plant cover estimafes being made within 415 of these sample units. In grasslands, 700, $1 / 4-m^{2}$ quadrats placed randomly along transects provided the basis for vegetation analysis. That was supplemented by the use of a smaller number of $100-m^{2}$ quadrats positioned relative to soil mapping units.

\section{Results}

Though some verifications of plant identification are yet to be done, over 200 vascular plant species have been recognized. These include 155 forbs (herbaceous plants which are not grasslike), 39 graminoids (grasses and grasslike plants), 18 shrubs and 5 trees. These are representatives of grasslands, riparian woodlands, river-edge zones and disturbed habitats. Accompanying the various 
native species are a number of exotic species, some of which are now very successful. Some native species are locally infrequent, however, truly unique and endangered species have not been noted.

As part of the ground surveys, noxious weed problems were included, and for leafy spurge (Euphorbia podperae), perhaps the most serious pest, all occurrences were mapped. Most of these are on portions of the floodplain and vary in size and density, some being significant infestations, others being small numbers of individuals. That information has already been supplied to the Historic Site personnel concerned with vegetation management. Poison ivy (Taxicodendron fydbergii) is another problem in one woodland area, and possible control measures are still being investigated.

Lesser problems with undesirable plant species occur in some of the former agricultural land now reseeded to grass cover. Here, wheatgrasses (Agropyron cristatum, A. intermedium, A. smithii), sideoats grama (Bouteloua curtipendula) and smooth brome (Bromus inermis) comprise the bulk of grass cover. While not always closely resembling the native prairie vegetation, some reseedings are effective cover plantings. In one complex of oldfields, however, grass cover has not been well established, and further revegetation efforts will be needed. Soil Conservation Service personnel familiar with such problems have been consulted about appropriate seeding methods and mixtures.

Those vegetation analyses completed so far reveal the overall nature of the native plant communities. The most extensive grasslands occur on upper slopes marked by irregular terrain and relatively coarse-textured soils. Needle-and-thread (Stipa comata), blue grama (Bouteloua gracilis), threadleaf sedge (Carex filifolia), junegrass (Koeleria pyramidata) and western wheatgrass (Agropyron smithii) dominate these sites. That is much like the mixed grass prairie found elsewhere in western North Dakota (Whitman and Wali 1975). Total plant diversity appears somewhat reduced, perhaps due to both local soil conditions and the long history of human impact.

Along lower slopes and ravines, moisture and other microclimatic features become more favorable (Whitman 1979), leading to composition shifts and greater productivity. Green needlegrass (Stipa viridula), sideoats grama, western wheatgrass, little bluestem (Andropogon scoparius), Kentucky bluegrass (Poa pratensis) and occasionally big bluestem (Andropogon gerardi) appear, along with some forbs and shrubs, e.g., buckbrush (Symphoricarpos occidentalis), chokechery (Prunus virginiana) and buffaloberry (Shepherdia argentea).

One small area of stabilized sand dunes occurs between the Missouri and Knife Rivers, and these are covered by a mosaic of shrub and tree clumps and interspersed grasslands.

The lowermost terrace and contemporary floodplain, where not wooded or formerly cultivated, contain small amounts of mesic prairie. These are evident because of an abundance of big bluestem. Sideoats grama, green needlegrass, western wheatgrass, infrequently Canada wildrye (Elymus canadensis) and switchgrass (Panicum virgatum) also appear. 
Especially at lower elevations where grass and shrub production are higher there has been an accumulation of standing dead and litter material. To avert a wildfire hazard and to perpetuate preferred native species, prescribed burning should be contemplated, and recommendations will be developed for inclusion in the final report.

Woodlands occupy much of the floodplain and part of an adjacent terrace. Along the edge of the Missouri River channel and at the confluence with the Knife River, cottonwood (Populus deltoides) is the primary tree. These cottonwood stands are in good condition and are of intermediate age. As typical throughout the region (Killingbeck 1978), cottonwood is a successional species, and its continued existence is attributable to new habitats being created with ongoing river meandering. This can be seen on and around the Historic Site, offering a clear demonstration of the dynamic nature of Missouri floodplain environments. That is of interest both for management and interpretive purposes.

Green ash (Fraxinus pennsylvanica), boxelder (Acer negundo) and American elm (Ulmus americana) gradually appear with cottonwood, and on older sites these become dominants as the cottonwoods age and die (Burgess et al 1973). At Knife River American elm is less common than the other two species, which can be viewed as co-dominants. These ash-boxelder woodlands exhibit several traits. Trees are relatively young, often less than 75 years old, and even in the northeast part of the Site, which bears the best quality woodlands, large green ash examined so far appear to be about a century old. This relative youthfuiness likely relates to two causes: repeated cutting by earlier inhabitants and natural mortality (rapid turnover), especially due to storm damage, periodic moisture stress and infection by a heartrot fungus, Fomes fraxinophilis. That latter point is supported by the observation that, though the trees are quite young, there is a significant amount of decadence and mortality.

While trees are comparatively young, densities are not especially high. The woodlands are open and of low stature. Past cutting and grazing are the likely reasons. Two other woodland features are probably due to these earlier impacts. There is little evidence of recent forest regeneration. For much of the woodland area tree seedlings and young saplings are infrequent. Besides being directly eliminated by grazing, there has been competitive exclusion by smooth brome, which now dominates the forest understory in many places. It has supplanted much of the native forest understory as well as inhibiting tree reproduction. It is unclear if the elimination of grazing will lead to an immediate recovery of the woodlands. It is almost as though the entry of smooth brome, faciliated by earlier human activities, has now altered forest successional patterns. If that is the case, woodland regeneration might be stimulated by selective cutting, which will trigger basal sprouting. Scattered examples of such vegetative regeneration can be seen, but intense deer browsing is an impediment.

The fourth objective entails relating the current vegetation to what might have existed at earlier times, e.g., the time of the Lewis and Clark Expedition. Historical documents are still being examined. Detailed observations about vegetation were seldom made, but some comparisons will be possible. The remaining grasslands probably bear a strong resemblance to the early 19th 
century antecedents and should be used more extensively in future natural history interpretive efforts at the Historic Site. Woodlands contain the same dominant tree species as earlier, but community composition and structure have been altered, as described above.

\section{Conclusions}

The floristic inventory reveals a comparatively diverse flora for an area of only 1300 acres, which has had a long history of human settlement. That diversity is attributable to a combination of varied terrain and soil conditions, the occurrence of several types of plant communities, and past human activities. Extant grasslands are of quite good quality, i.e., they are much like other areas of native mixed grass prairie in the region. Woodlands, now as in the past, are a prominent part of the Site, however, they show a strong influence by anthropogenic factors. Fitting this into an historical context and considering possibilities for management and interpretation are efforts to be completed during the remainder of the project.

\section{Literature Cited}

Burgess, R. L., W. C. Johnson and W. R. Keammerer. 1973. Vegetation of the Missouri River floodplain in North Dakota. ND Water Resources Res. Inst,, Fargo. 162 pp.

Killingbeck, K. T. 1978. Vegetation structure and succession of cottonwood (Populus deltoides) communities in western North Dakota. Proc. ND Acad. of Sci. 32(1):1. Abs.

Whitman, W. C. 1979. Analysis of grassland vegetation on selected key areas in southwestern North Dakota. ND Reg. Envir. Assessment Prog. Proj. Rept. No. 79-14. ND State Univ., Fargo. 199 pp.

Whitman, W. C. and M. K. Wali. 1975. Grasslands of North Dakota. Pages 53-73 in M. K. Wali, ed. Prairie: A multiple view. Univ. of ND Press, Grand Forks. 